\title{
Estimation of energy potential of agricultural enterprise biomass
}

\author{
Vasyl Lypchuk ${ }^{1, *}$, Kateryna Syrotiuk ${ }^{2}$ \\ ${ }^{1}$ Kielce University of Technology, Faculty of Management and Computer Modelling, 25-314, Kielce, \\ Poland \\ ${ }^{2}$ Lviv National Agrarian University, Faculty of Economics, 80381, Lviv-Dublany, Ukraine
}

\begin{abstract}
Bioenergetics (obtaining of energy from biomass) is one of innovative directions in energy branch of Ukraine. Correct and reliable estimation of biomass potential is essential for efficient use of it. The article reveals the issue of estimation of potential of biomass, obtained from byproducts of crop production and animal breeding, which can be used for power supply of agricultural enterprises. The given analysis was carried with application of common methodological fundamentals, revealed in the estimation of production structure of agricultural enterprises, structure of land employment, efficiency of crops growing, indicators of output of main and by-products, as well as normative (standard) parameters of power output of energy raw material in relation to the chosen technology of its utilization. Results of the research prove high energy potential of byproducts of crop production and animal breeding at all of the studied enterprises, which should force its practical use.
\end{abstract}

\section{Introduction}

Bioenergetics is an important direction for development of the sector of renewable sources of energy in Ukraine, because large potential of biomass, available for the energy production, is concentrated here.

Use of energy, produced of by-products of crop production and animal breeding, is an actual and prospective direction of economic activity, securing increase of its marketability level and economic stability of agricultural enterprises. Besides, growing of biomass for energy purposes can be a separate direction of activity at agricultural enterprises.

According to the data of energy balances of Ukraine in 2010, the whole bioenergetics substituted 1,1 bln $\mathrm{m}^{3}$ of gas in a year [1], and the indicator made $3 \mathrm{bln}^{3}$ of gas in 2014 [2]. Share of renewable sources of energy made $2,6 \%$ of the total supply of primary energy in 2014. Total supply of primary energy of biomass increased to $1,934 \mathrm{mln} t$ of o.e., that equals $2,25 \mathrm{bln}^{3}$ of gas, and above $3,15 \%$ more than in 2013 .

In 2010-2014, increase rate made $42 \%$ annually. If the rate is kept till 2020 , bioenergetics will be capable to produce 5,4 bln $\mathrm{m}^{3}$ of gas in a year.

\footnotetext{
*Corresponding author: wlipczuk@tu.kielce.pl
} 
Europe-integration attempts of Ukraine and reforming of its economy demonstrate that Ukraine's energy branch should be developed in the direction, which corresponds to the European standards and vectors. In the European Union, share of renewable sources makes $15 \%$ (as of 2013) in the gross ultimate energy consumption (GUE), including biomass - about $9 \%$ of GUE or $62 \%$ of all RSE. In some countries of the EU, the share of biomass among all renewable sources fluctuates between 30-40\% (Luxemburg, Cyprus, Ireland), up to 80-95\% (Estonia, Latvia, Lithuania, Hungary, Poland, Finland). Until 2010, share of RSE in the gross ultimate energy consumption of the EU should make 20\% (obligatory target), and it can achieve at least $27 \%$ (new obligatory target, set by the European Commission in October 2014) until 2030 [3].

The European Commission developed Energy Roadmap 2050 [4], analyzing ways to achieve the set targets as to cut of emission of greenhouse gas, securing reliability and competitive capacity of energy supply systems. In the Roadmap, the EU describes five possible scenarios of power engineering development. "Scenario of RSE" is coordinated with the forecast of development prospects of the EU power engineering, launched by the European Commission on RSE (EREC) - "RE-Thinking 2015" [5].

It is known, that consumption of energy should be based on the principles of reasonability and correspond to ideas of the theory of sustainable development of an economy. Thus, rationalization of the use of biomass energy needs persistent systematic work, focused at optimization of each economic process. Considering the existing resource potential and large amount of unemployed agricultural lands, bioenergetics is a prospective direction for domestic producers.

Efficient use of the potential of agricultural enterprises biomass is possible under application of an appropriate mechanism, practically revealed in a set of managerial decisions, aimed at solution of energy tasks.

Correct and reliable estimation of agricultural biomass potential is an essential precondition for efficient use of it.

Aim of the research is to estimate possibilities of self-energy-supply of technological processes of agrarian production, depending on specialization of enterprises and basing on determination of potential of agricultural biomass, which can be used for energy purposes.

Object of the research is made by energy potential of by-products of crop production and animal breeding at agricultural enterprises with different specialization. The research was carried out on the base of agricultural enterprises in Lviv region, demonstrating rather dynamic development of bioenergetics.

\section{Study of energy potential of agricultural enterprise biomass}

Research on the energy potential of biomass was made with application of common methodological principles, revealed in the estimation of production structure of agricultural enterprises, structure of lands employment, efficiency of agricultural crops growing, including energy ones, indicators of output of the main and by-products, as well as normative (standard) parameters of energy output of the energy raw material according to the chosen technology of its utilization.

To estimate energy potential of by-products of crop production and animal breeding we made grouping of agricultural enterprises according to their production structure and determined four the brightest examples of typical enterprises with different structure of products (only products of crop production, with production of goods of crop production and animal breeding, taking different share in the total structure of commodity products), in particular:

LLC "Brody Agro" deals only with production of crop products, specializing in growing of cereals and industrial crops (Figure 1). 


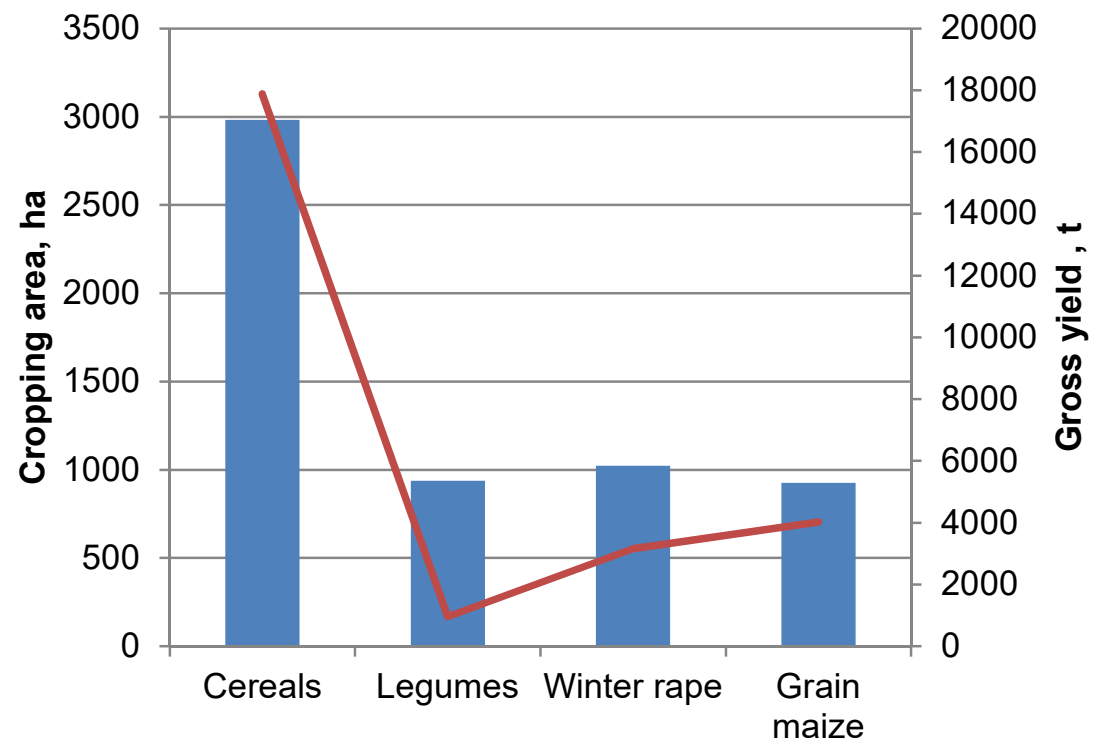

Cropping area, ha $\longrightarrow$ Gross yield, $\mathrm{t}$

Fig.1. Cropping area and gross yield of agricultural crops at the $1^{\text {st }}$ type enterprise.

PIE "Bilyi Stik" is engaged in production of crop products and animal breeding, with privilege to animal breeding. It is specialized in production of beef and dairy cattle, and in crop production - specialized in cereals growing (Figure 2).

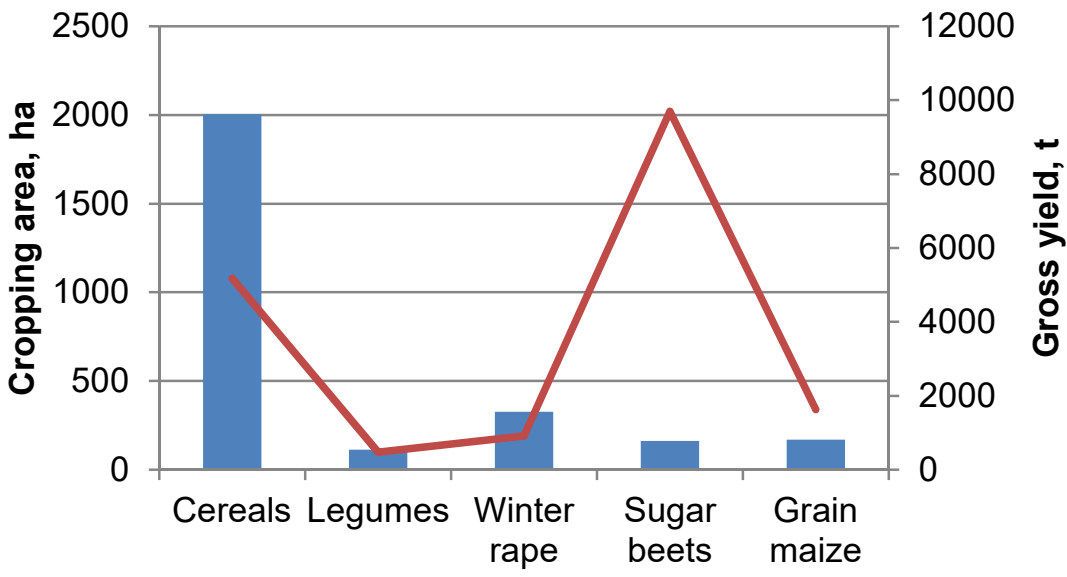

Cropping area, ha Gross yield, $\mathrm{t}$

Fig. 2. Cropping area and gross yield of agricultural crops at the $2^{\text {nd }}$ type enterprise. 


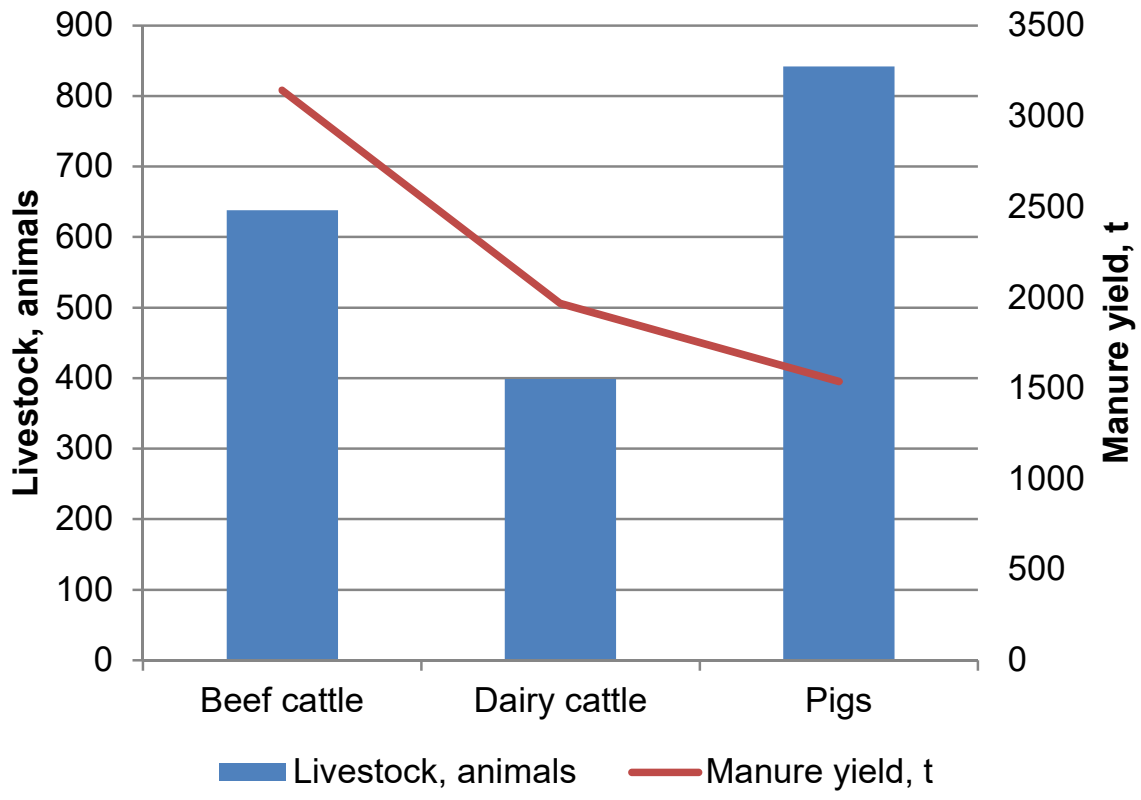

Fig. 3. Animals of cattle and amount of manure production at the $2^{\text {nd }}$ group enterprise.

PE "Agro-Progres" deals with production of crop products and animal breeding, with accent to crop production. It is specialized in cereals growing and production of pig-raising products (Figure 3).

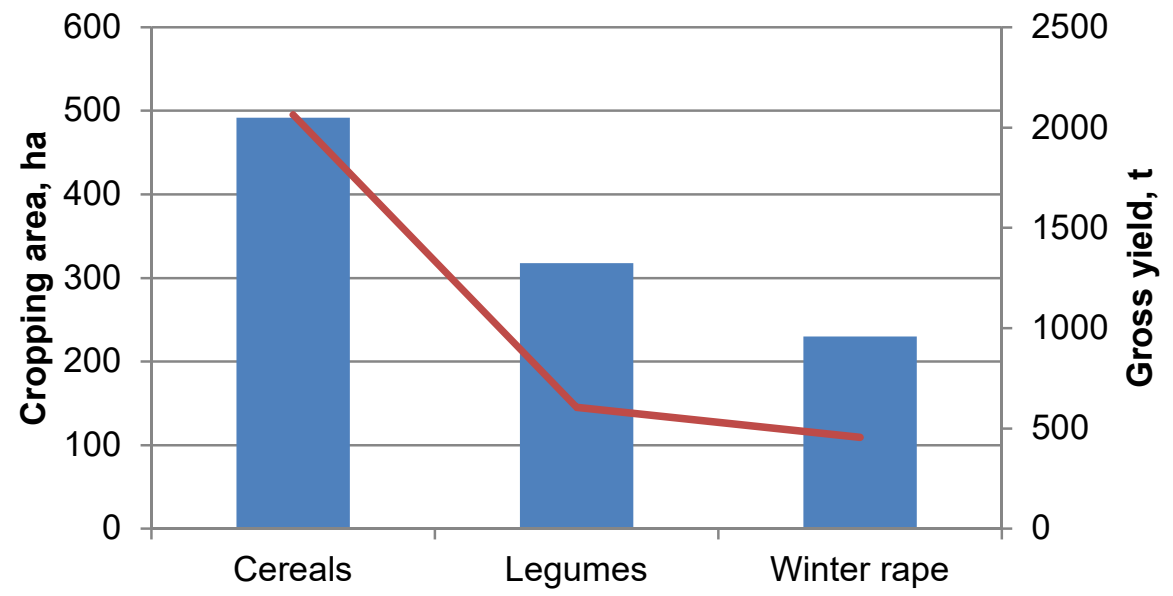

Cropping area, ha $\longrightarrow$ Gross yield, $\mathrm{t}$

Fig. 4. Cropping area and gross yield of agricultural crops at the $3^{\text {rd }}$ type enterprise.

Number of pigs makes 86 animals, supplying $156 \mathrm{t}$ of manure.

LLC named after Danylo Halytskyi produces crop products and products of animal breeding in equal volume. In crop production, it is specialized in growing of cereals and rape, and in animal breeding - in beef and dairy cattle (Figure 5,6). 


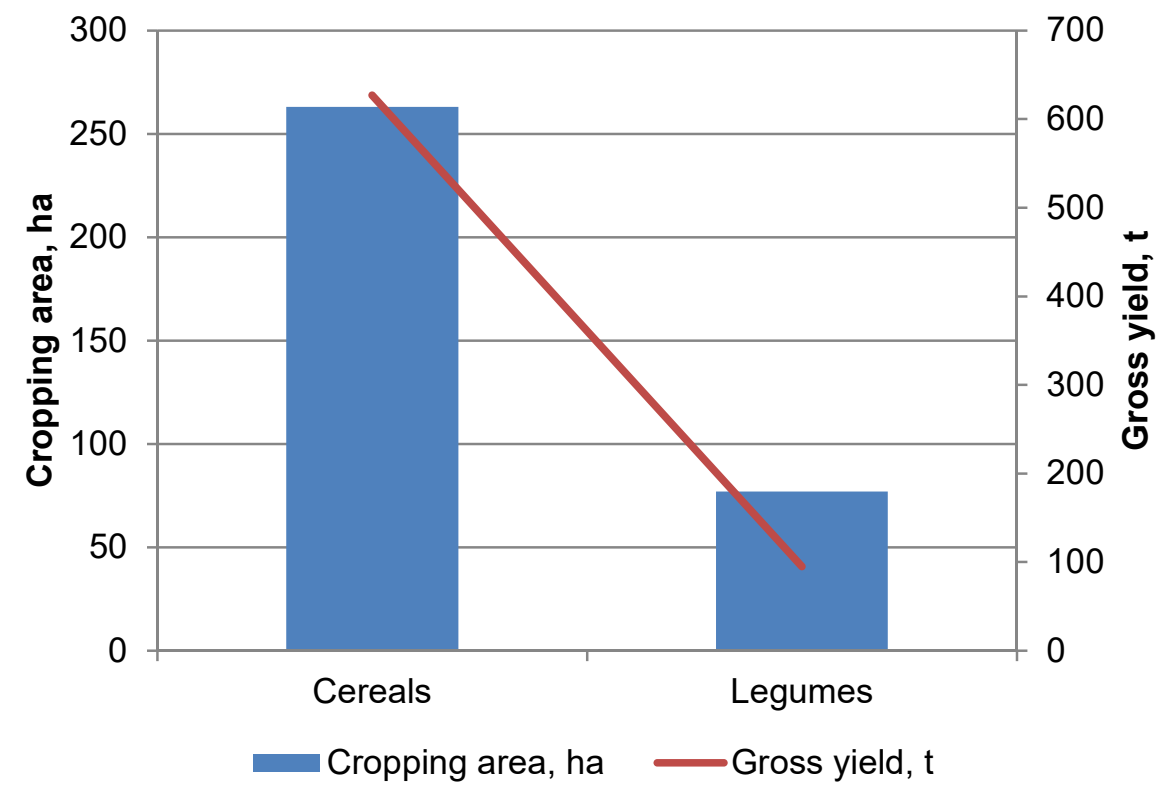

Fig. 5. Cropping area and gross yield of agricultural crops at the $4^{\text {th }}$ type enterprise.

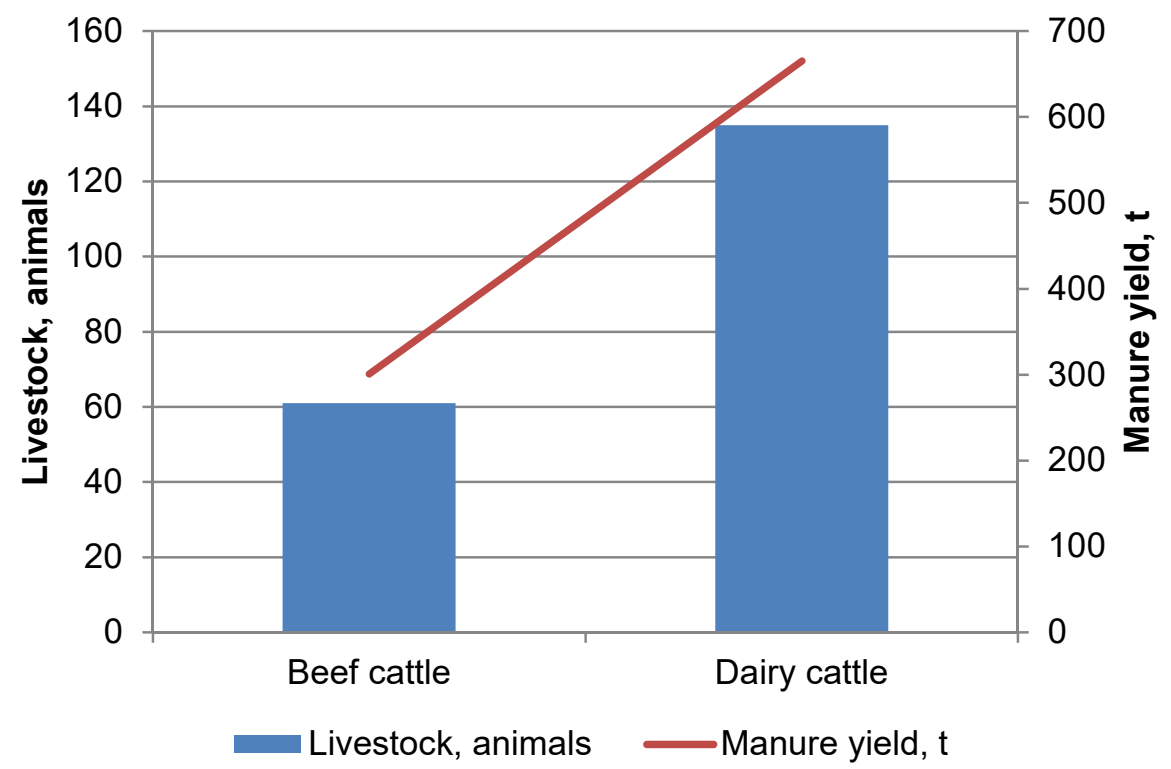

Fig. 6. Cattle livestock and amount of manure production at the $4^{\text {th }}$ type enterprise.

Such differentiation of enterprises enables estimation of the amount of by-products of crop production and animal breeding for energy purposes at the enterprises with different production structure.

To find out impact of the amounts of production of agricultural products at the investigated enterprises, we make their energy estimation by consolidated indexes [6-11]. 
To estimate energy potential $\left(\mathrm{E}_{\mathrm{cr}}\right)$ of residues from crop production, in particular in Ukraine and Poland, they use the following formula:

$$
E_{c r}=V \cdot K_{1} \cdot K_{2} \cdot K_{3} \cdot Q_{l s h}^{c r},
$$

where $V$ - volume of main products, ton;

$K_{1}$ - coefficient of by-products;

$K_{2}$ - coefficient of by-products availability;

$K_{3}$ - coefficient of by-products use for technological needs;

$Q_{l s h}^{c r}-$ low specific heat of biological by-products combustion, GJ/t.

Coefficient of by-products is made by correlation of dry matter of crop by-products of a certain crop to weight of the obtained yield.

Coefficient of by-products availability is considered as a share of total amount of crop by-products, which can be actually harvested, i.e. generally available for utilization.

Coefficient of by-products use for technological needs is calculated by deduction of the share of biomass, which can be used for other agricultural needs (silage, bedding, forage products, etc.)

To determine energy potential of by-products from animal breeding one can apply two methods $[6,7]$.

The first one is to determine amount of secondary raw material (manure) and biogas yield on its base with consideration of its heating value.

The second one is to determine amount of normative biogas yield per a head of cattle.

We used the first method, as it is able to give accurate description of energy characteristics of secondary raw materials. Thus, energy estimation of secondary products of animal breeding can be made with application of the following formula:

$$
E_{a n}=n_{a} \cdot K_{m y} \cdot M_{m y} \cdot Q_{l h v}^{b g},
$$

where $n_{a}$ - livestock of cattle, animals;

$K_{m y}$ - manure yield from one animal of cattle, t/animal;

$M_{m y}$ - normative (standard) biogas yield from a ton of manure, $\mathrm{m}^{3} / \mathrm{t}$;

$Q_{l h v}^{b g}$ - low heating value of biogas, $\mathrm{GJ} / \mathrm{m}^{3}$.

Basing on the above-mentioned methods it is necessary to make estimation of energy potential of by-products from crop production and animal breeding in terms of the investigated enterprises.

To make consolidated comparative estimation of specific energy potential of each of the studied enterprises we determined its value per 1 ha of arable land and agricultural land (Table 1-4).

Table 1. Amount and energy potential of crop production by-products at the $1^{\text {st }}$ type enterprise.

\begin{tabular}{|c|c|c|c|c|}
\hline Indicators & Cereals & Legumes & Winer rape & $\begin{array}{c}\text { Grain } \\
\text { maize }\end{array}$ \\
\hline Energy by-product, t & 11285 & 364 & 2657 & 781 \\
\hline Energy potential, GJ & 178305 & 5095 & 38533 & 12498 \\
\hline $\begin{array}{c}\text { Specific energy potential, GJ/ha } \\
\text { of arable land }\end{array}$ & 59.77 & 5.43 & 37.70 & 13.50 \\
\hline $\begin{array}{c}\text { Specific energy potential, GJ/ha } \\
\text { of agricultural land }\end{array}$ & 30.09 & 0.86 & 6.50 & 2.11 \\
\hline
\end{tabular}

Analysis of the table 1 shows that main energy potential is demonstrated by cereals both in total amount and by specific indicators. 
Table 2. Amount and energy potential of agricultural by-products at the $2^{\text {nd }}$ type enterprise.

\begin{tabular}{|c|c|c|c|c|c|c|c|c|}
\hline Indicators & Cereals & $\begin{array}{c}\text { Legum } \\
\text { es }\end{array}$ & $\begin{array}{c}\text { Winter } \\
\text { rape }\end{array}$ & $\begin{array}{c}\text { Sugar } \\
\text { beets }\end{array}$ & $\begin{array}{c}\text { Grain } \\
\text { maize }\end{array}$ & $\begin{array}{c}\text { Beef } \\
\text { cattle }\end{array}$ & $\begin{array}{c}\text { Dairy } \\
\text { cattle }\end{array}$ & Pigs \\
\hline $\begin{array}{c}\text { Energy by- } \\
\text { product, } \\
\left(\mathrm{m}^{3}\right)\end{array}$ & 3265 & 182 & 773 & 4540 & 315 & 314375 & 196607 & 99882 \\
\hline $\begin{array}{c}\text { Energy } \\
\text { potential, } \\
\text { GJ }\end{array}$ & 51584 & 2545 & 11213 & 14991 & 5045 & 7274.6 & 4549.5 & 2311.3 \\
\hline $\begin{array}{c}\text { Specific } \\
\text { energy } \\
\text { potential. } \\
\text { GJ/ha of } \\
\text { arable land }\end{array}$ & 25.73 & 22.52 & 34.40 & 92.54 & 29.85 & 11.4 & 11.4 & 2.7 \\
$\begin{array}{c}\text { Specific } \\
\text { energy } \\
\text { potential. } \\
\text { GJ of } \\
\text { agricultural } \\
\text { land }\end{array}$ & 20.58 & 1.02 & 4.47 & 5.98 & 2.01 & 2.90 & 1.81 & 0.92 \\
\hline
\end{tabular}

Data of the Table 2 prove that enterprises. growing industrial crops have rather high specific energy potential. It is particularly true for by-products from sugar beets growing. Regardless of the considerable amount of produced manure. both specific and energy potential is insufficient. In our case. it is explained by low energy efficiency of manure utilization.

Table 3. Amount and energy potential of agricultural by-products at the $3^{\text {rd }}$ type enterprise.

\begin{tabular}{|c|c|c|c|c|}
\hline Indicators & Cereals & Legumes & Winter rape & Pigs \\
\hline Energy by-product. $\mathrm{t}\left(\mathrm{m}^{3}\right)$ & 1302 & 229 & 383 & 10202 \\
\hline Energy potential. GJ & 20572 & 3207 & 5552 & 236.1 \\
\hline $\begin{array}{c}\text { Specific energy potential. } \\
\text { GJ/ha of arable land }\end{array}$ & 41.81 & 10.09 & 24.14 & 2.7 \\
\hline $\begin{array}{c}\text { Specific energy potential. } \\
\text { GJ/ha of agricultural land }\end{array}$ & 8.21 & 1.28 & 2.21 & 0.09 \\
\hline
\end{tabular}

Results of the Table 3 prove that energy potential is mainly revealed by grain production by-products. similar to the previous examples. Utilization of by-products of pig raising also demonstrates low energy efficiency because of small livestock.

Table 4. Amount and energy potential of agricultural by-products at the $4^{\text {th }}$ type enterprise.

\begin{tabular}{|c|c|c|c|c|}
\hline Indicators & Cereals & Winter rape & Beef cattle & Dairy cattle \\
\hline Energy by-product. t & 396 & 36 & 30058 & 66521 \\
\hline Energy potential. GJ & 6252 & 522 & 695.5 & 1539.3 \\
\hline $\begin{array}{c}\text { Specific energy potential. } \\
\text { GJ/ha of arable land }\end{array}$ & 23.8 & 6.8 & 11.4 & 11.4 \\
\hline $\begin{array}{c}\text { Specific energy potential. } \\
\text { GJ/ha of agricultural land }\end{array}$ & 12.33 & 1.03 & 1.37 & 3.04 \\
\hline
\end{tabular}


Analysis of the table 4 proves that energy efficiency of cereals growing prevails over products of animal breeding.

\section{Estimation of the level of energy substitution at agricultural enterprises}

Considering the fact that the investigated enterprises have different area of agricultural lands and apply different technologies to grow agricultural products. it is reasonable to determine coefficient of energy substitution. characterizing correlation of energy potential of byproducts to energy needs of agricultural production. To calculate it we use the following formula:

$$
K_{e s}=\frac{E_{c r}+E_{a n}}{N_{e}} .
$$

where. $N_{e}-$ are equivalent energy needs of agricultural enterprise. GJ.

Equivalent energy needs are determined according to the volume of consumed kinds of fuel and electric energy. calculated in energy unit (GJ) (Table 5).

Table 5. Estimation of energy capacity of utilized energy resources at the enterprises of different types.

\begin{tabular}{|c|c|c|c|c|c|c|c|c|}
\hline \multirow{2}{*}{ Indicators } & \multicolumn{2}{|c|}{1 type } & \multicolumn{2}{c|}{ 2 type } & \multicolumn{2}{c|}{3 type } & \multicolumn{2}{c|}{ type } \\
\cline { 2 - 9 } & $\begin{array}{c}\text { Liquid } \\
\text { fuel. } \\
\mathbf{t}\end{array}$ & $\begin{array}{c}\text { Electric } \\
\text { energy. } \\
\mathbf{k W / h}\end{array}$ & $\begin{array}{c}\text { Liquid } \\
\text { fuel. } \\
\mathbf{t}\end{array}$ & $\begin{array}{c}\text { Electric } \\
\text { energy. } \\
\mathbf{k W / h}\end{array}$ & $\begin{array}{c}\text { Liquid } \\
\text { fuel. } \\
\mathbf{t}\end{array}$ & $\begin{array}{c}\text { Electric } \\
\text { energy. } \\
\mathbf{k W / h}\end{array}$ & $\begin{array}{c}\text { Liquid } \\
\text { fuel. } \\
\mathbf{t}\end{array}$ & $\begin{array}{c}\text { Electric } \\
\text { energy. } \\
\mathbf{k W / h}\end{array}$ \\
\hline $\begin{array}{c}\text { Number of } \\
\text { units }\end{array}$ & 405 & 91395 & 140 & 494574 & 67 & 40775 & 19 & 17442 \\
\hline $\begin{array}{c}\text { Energy } \\
\text { capacity. } \\
\text { GJ }\end{array}$ & 17390 & 329 & 6030 & 1780 & 2868 & 147 & 809 & 63 \\
\hline
\end{tabular}

Data of the table 5 prove that transportation and field works take the main share of energy needs that is argued by large volume of purchased liquid fuel. The volume exceeds the need of electric energy in energy equivalent.

Comparative estimation of energy efficiency of agricultural production at the studied enterprises is presented in the Table 6 .

Table 6. Integrated indicators of energy potential of agricultural by-products. energy needs of an enterprise and coefficient of its energy supply.

\begin{tabular}{|c|c|c|c|c|}
\hline Indicators & 1 type & 2 type & 3 type & 4 type \\
\hline Energy potential of crop production. GJ & 234431 & 85378 & 29331 & 6774 \\
\hline Energy potential of animal breeding. GJ & 0 & 14135 & 236 & 2235 \\
\hline Total energy potential. GJ & 234431 & 99513 & 29567 & 9009 \\
\hline Need of energy. GJ & 17719 & 7810 & 3014 & 872 \\
\hline Coefficient of energy supply & 13 & 13 & 10 & 10 \\
\hline
\end{tabular}


Data of the table 6 prove that. according to the coefficient of energy supply. all studied enterprises can be energy self-sustainable. It means that amount of theoretical energy potential of by-products is larger than their energy needs.

Actual level of energy supply first depends on technology and efficiency of secondary by-products utilization.

\section{Conclusions}

The carried research proves that amount of energy potential of crop production by-products considerably depends on yield capacity of agricultural crops. which has two constituents: the first one is based on dynamics of yield capacity rise and is forecasted to some degree; the second one - depends on changeable character of weather conditions and has scholastic character. Speaking about products of animal breeding. relatively low energy efficiency of by-products results in insufficient share of it in the structure of energy balance of an enterprise. However. it does not mean that there is no need to make manure utilization. It is connected with the fact that in the process of manure utilization the main share of efficiency is provided by ecological. agrotechnical and social component.

The carried analysis of the estimation of by-product energy potential was made on the base of the data. not reflecting dynamics of development of crop production and animal breeding at the investigated enterprises and without consideration of the impact of naturalclimatic conditions on farming activity.

Considering dynamics of productive activity of the enterprises and changeable natural conditions. prospective estimation of the level of energy substitution of agricultural production should be based on the results of scholastic modelling of its energy consumption and energy supply.

\section{References}

1. Energy balance of Ukraine. 2010. Available at: http://www.ukrstat.gov.ua/operativ/operativ2012/energ/en_bal/arh_2012.htm

2. Energy balance of Ukraine. 20̄14. Available at: http://www.uabio.org/img/files/news/pdf/energy-balance-ukraine-2014.pdf

3. G.G. Geletuxa. T.A. Zhelyezna. P.P. Kucheruk. Ye.M. Olijny`k. The current state and prospects of bioenergy development in Ukraine. 9. 32 (Policy Brief BAU 2014)

4. Energy Roadmap 2050. $\operatorname{COM}(2011) 885$ final. 15.12.2011. Available at: https://ec.europa.eu/energy/sites/ener/files/documents/2012_energy_roadmap_2050_en_ $0 . p d f$

5. RE-Thinking 2050. A 100\% Renewable Energy Vision for the European Union. EREC (2010)

6. G.G. Geletuxa T.A. Zheleznaya M.M. Zhovmir Yu.B. Matveyev O.I. Drozdova Evaluation of the energy potential of biomass in Ukraine. Part 2: energy crops. liquid biofuels. biogas. Industrial heat. 33. 57-64 (2011)

7. V.O. Dubrovin. H.H. Heletukha. and S.H. Kudria. Methods generalized assessment of technically achievable energy potential of biomass. Viol_prynt. Kyiv. Ukraine. 25 (2013).

8. B. Koscik. Bioenergy of Subcarpathian (Jaroslaw. 2007)

9. W. Podkowka Z. Podkowka. A. Kowalczyk-Jusko. P. Pasyniuk. Agricultural biogas renewable source of energy. Theory and practical application (Warsaw. 2012)

10. W. Lewandowski. M. Ryms. Biofuels. Environmentally friendly renewable sources of energy (Warsaw. 2013)

11. A. Grzybek. P. Gradziuk. K. Kowalczyk. Straw - energy fuel (Warsaw. 2001) 